\title{
Musical Aptitude Testing: From James McKeen Cattell to Carl Emil Seashore
}

\section{Jere T. Humphreys}

\section{Abstract}

The purpose of this article is to describe the links between late nineteenth-century psychological research and the early musical aptitude research of Carl Emil Seashore (18661949). The primary link was the music-related research of the leader of the mental testing movement during the 1890s, Columbia University psychologist James McKeen Cattell (1860-1944). German psychologist Wilhelm Wundt instructed Cattell in the German scientific tradition, and English researcher Francis Galton encouraged Cattell's research on individual differences and introduced him to statistical methods. During the 1890 s, Cattell conducted a longitudinal study, the hypothesis for which was that tests of sensory discrimination ability, including musical discrimination, would correlate with undergraduates' academic grades. After his study failed to produce the expected results, the mental testing movement followed Alfred Binet and Victor Henri of France, and Cattell tumed to other activities. However, in the meantime, Cattell influenced many other important psychologists, including Edward W. Scripture, Carl Seashore's doctoral mentor at Yale University, and eventually Seashore himself. Despite the mental testing movement's shift to Binet and Henri's cognitive-type testing, Seashore continued his conservative, sensory approach to the testing of musical aptitude.

W hen psychologist Carl Emil Seashore (1866-1949) began the two decades of research that led to the development of his famous tests of musical aptitude, ${ }^{1}$ he drew upon beliefs and research methods then prevalent in the field of psychology. Many of those beliefs and methods were examined in a previous article. ${ }^{2}$ The purpose of this article is to describe the remaining major links between late nineteenthcentury music-related psychological research and Seashore's early work: the music-related research of James McKeen Cattell (1860-1944), the leader of the mental testing movement during the $1890 \mathrm{s.}^{3}$

In the 1890s, European and American researchers in the new field of scientific, empirical, laboratory-based psychology (as opposed philosophical "armchair" psychology) focused their research on sensory perception, the first of the new psychology's three "great topics." 4 At about the same time, American psychologists assumed the leadership in mental testing research, which was part of the new psychology. Carl Seashore undertook his doctoral studies in the first half of the 1890s, a period that coincided with the birth of sensory psychology and mental testing research in the United States. Not long thereafter, he applied the methods of scientific psychology and mental testing to his research on musical aptitude.

\section{Perception Research}

Speculation about sensory perception began in Ancient Greece. Empirical research on the same began during the Renaissance, including studies of the least discernible differences in musical pitch. Theoretical and empirical perception research by Ernst Heinrich Weber (1795-1878), Gustav Theodor Fechner (1801-1887), Hermann Ludwig Ferdinand von Helmholtz (1821-1894), and other physicists led to a fusion of philosophical speculation and physiological research on sensation, which in turn contributed significantly to the emergence of the field of modern psychology. Wilhelm Wundt (1832-1920) of the University of Leipzig, the world's first famous psychologist, borrowed testing ideas and research methods from these early researchers and helped develop the subfields of experimental psychology and psychophysics. 5 
Cambridge University researcher Francis Galton (1822-1911) borrowed sensory perception research methods from Wundt and others. An adherent of the long-standing belief that all knowledge is obtained through the five senses, Galton was also influenced by Charles Darwin's (1809-1882) theory of evolution, the natural selection properties of which implied individual differences between people; ${ }^{6}$ the widespread belief in faculty psychology, whose adherents held that sensory faculties correspond to faculties of the brain; the emergence of atomistic chemistry, which encouraged psychologists to study the "psychological elements," or senses; and the development of the concept of the normal, or random, distribution curve.

Eventually, Galton hypothesized that "a measure of sensory acuity would provide a crude measure of a person's level of intelligence," and that mental ability is normally, or randomly, distributed. ${ }^{8}$ He also came to believe that mental abilities are related to each other, which led him to develop the rudiments of statistical correlation. ${ }^{9}$ Unlike Wundt, who attempted to identify traits common to all (or most) people, Galton used Wundt's methods to measure individual differences in mental ability. Galton's research, which began in the 1870s, included tests of musical discrimination and perception. ${ }^{10}$

\section{James Cattell}

Leadership of the mental testing movement passed from Galton in the $1880 \mathrm{~s}$ to James Cattell in the 1890s. Cattell graduated from Lafayette College in Easton, Pennsylvania, where his father was president, in 1880 . For the next several years, he divided his time between completing a master's degree at Lafayette, working on a Ph.D. in psychology under Wundt (granted in 1886), studying with Galton at Cambridge, and several other activities. One of those activities was a graduate fellowship at Johns Hopkins University (1882-83), where he and fellow graduate students (two of whom were John Dewey and Joseph Jastrow) helped G. Stanley Hall (1844-1924) establish one of the first American psychological laboratories. ${ }^{11}$ He went to the University of Pennsylvania in the late 1880s, where he opened a psychological laboratory and held the first university faculty position in psychology in the United States. After moving to Columbia University in 1891, he provided leadership to the new experimental psychology movement for the next twenty-six years. ${ }^{12}$

Cattell seems to have begun his sensory perception studies while at Johns Hopkins in $1883 .{ }^{13}$ He continued at least one of those experiments in Wundt's laboratory. ${ }^{14} \mathrm{He}$ also seems to have developed his keen interest in experimental apparatus at Leipzig, including those for music research:

We have in the [Wundt's] laboratory two excellent pieces of apparatus for testing the power of distinguishing notes. The one is an organ arrangement, which gives the notes at intervals of four vibrations from 32 to 1024 [Hz.] . . The other apparatus is a set of tuning forks made up by König [sic], in Paris. Pairs of tuning forks are taken, one always gives the same note, the other (by means of weights) can be so regulated as to give a note a little lower or higher. Experiments on this subject are being made by three groups of students . . In one case, memory of notes is being especially investigated. ${ }^{15}$

Similarly, in 1888, Cattell described "[c]areful experiments, not yet published," that had "been carried on for several years past in the Leipsic [sic] laboratory" on the least perceptible differences in loudness and pitch, and on the perception of musical intervals. ${ }^{16}$

Cattell also seems to have first become interested in individual differences during his time with Hall at Johns Hopkins. ${ }^{17}$ He took that interest with him to Leipzig, where Wundt, himself uninterested in individual differences, ${ }^{18}$ allowed Cattell to write a paper on the subject as early as $1885 .{ }^{19}$

Cattell's interest in individual differences intensified during his intermittent work with Galton at Cambridge over several years. For example, his letters from Cambridge tell of his "association experiments," 
Cattell studied extensively with Wundt, the early leader in the psychological measurement of sensory perception, and Galton, the pioneering mental tester and the early leader in the measurement of individual differences in sensory perception. The fact that both men incorporated tests of musical perception in their research appears to have influenced Cattell to do the same.

\section{Cattell the Mental Tester}

At the University of Pennsylvania, his first full-time position, Cattell gathered for the laboratory "a valuable collection of Koenig's [sic] apparatus for the study of hearing and the elements of music ..."21 Soon thereafter, in 1890, he published an article in a British journal that scholars believe was the first time the term "mental test" appeared in print. ${ }^{22}$ In this article, a watershed in the history of mental measurement, ${ }^{23}$ Cattell described a series of ten tests then in use at Pennsylvania. None of the ten tests involved music, although one measured "Reaction-time for Sound." However, Cattell listed an additional fifty tests still under development, "which I look on as the more important in order that attention may be drawn to them, and co-operation secured in choosing the best series of tests and the most accurate and convenient methods." Soms of these were music tests. ${ }^{24}$

Upon his arrival at Columbia, he established the department of psychology and developed what became known as the "Freshman Tests," which he administered to at least fifty volunteer freshmen each year beginning in 1893. Cattell held great hope for these tests, which he predicted would correlate with each other and with academic grades. In an 1896 article, Cattell and a collaborator described their research methods in some detail and provided preliminary results from what may have been the first predictive study of academic success. Only two tests related to music. For one, a test of hearing (of tones), the researchers simply divided subjects from each year into "normal," "subnormal," and "abnormal" categories. The other music test measured the "accuracy of the perception of pitch." After subjects heard a pitch ( $F$ below middle $C$ ) played on a monochord, they attempted to match the pitch by adjusting the instrument's bridge. ${ }^{25}$

After several more years of data collection, one of Cattell's graduate students, Clark Wissler, reported more results from the study, including data collected from a small number of female students from Barnard College. Wissler correlated the test scores with each other and with senior grade-point averages using the technique of statistical correlation that had been discovered by Galton and developed by Galton's young associate, Karl Pearson. ${ }^{26}$

Most of the instruments in the battery were tests of sensory discrimination. In addition to the pitch perception test described above, Wissler discussed a music-related test of "Rhythm and Perception of Time" that measured subjects' abilities to continue tapping a steady beat on a telegraph key fifty times after hearing a stimulus of ten tapped beats, and two "Imagery" questions that required written responses. ${ }^{27}$

On the pitch perception test, the "average error" (monochord bridge distance from the "correct" placement) was 7.2 centimeters for freshmen and 3.7 centimeters for seniors. Wissler concluded that women were superior to men and seniors were superior to freshmen on that test, with a "certainty of results" of $p<.01$ in each case. ${ }^{28} \mathrm{He}$ found no statistically significant differences in pitch perception between freshmen from different years. ${ }^{29}$

Unfortunately, with one exception, Wissler did not report correlation coefficients between the pitch perception test and the other variables. The exception was a coefficient of $\mathrm{r}=.01$ between pitch perception and reaction time $(\mathrm{N}=100)$. In general, he found only chance intercorrelations between the physical and mental tests, and moderate intercorrelations between grades for specific courses. Most disappointing of all, he found only chance correlations between individual tests taken as freshmen and overall grades as seniors. Among other things, Wissler complained about the inadequacy of 
undergraduate grades as a representative measure of students' abilities to handle "life tasks," which he deemed "exceedingly complex." He concluded that Cattell's physical and mental tests promised little "from a practical point of view."

\section{Other Mental Testers}

European researchers were beginning to conduct similar studies of mental functions in the 1890s. ${ }^{31}$ In the United States, where most of the work occurred, Frank Boas (1858-1942) related school children's test scores to their mental alertness as estimated by teachers; Joseph Jastrow (1863-1944) developed fifteen tests for college students; and James A. Gilbert (b. ?-d. ?) studied the mental and physical development of school children. Like Cattell and Wissler, Boas and Gilbert found only chance relationships between test scores and teacher ratings. ${ }^{32}$

More important than any of these mental testing efforts was the work of Alfred Binet (1857-1911) and Victor Henri (1872-1940) in France and Hugo Münsterberg (18631916) in the United States. These researchers experimented with a radically different type of mental test based on cognitive functioning rather than sensory perception..$^{33}$ Cattell seems to have recognized as early as 1896 the importance of these new tests:

of a strictly psychological character. For the psychologist these are, of course, the most interesting and important. But we are at present concerned with anthropometric work, and measurements of the body and of the senses come as completely within our scope as the higher mental processes. ${ }^{34}$

Indeed, the mental testing movement soon followed Binet and Henri's lead. Probably for that reason, Cattell, like Galton before him, turned to other interests. ${ }^{35} \mathrm{He}$ eventually became embittered, in part because "his major contribution to experimental psychology ... [was] thoroughly discredited and replaced by the . . . tests of Alfred Binet."36

\section{Cattell and Seashore}

Several pieces of evidence suggest that Cattell influenced Carl Seashore's work on musical aptitude testing. First, as a founding member and fourth president of the American Psychological Association, founding editor of the American Joumal of Psychology, founding head of the psychology department at a leading university (Columbia), and leader of the mental testing movement during the 1890s, James Cattell was an extremely prominent psychologist.

Second, Cattell was a professional friend of Edward Wheeler Scripture (18641945), Seashore's doctoral mentor at Yale University who himself had taken his doctorate under Wundt in 1891. Scripture was a highly productive researcher, but because of his disagreeable personality, he "was largely estranged from his generation of American psychologists," except for Cattell, his "best friend among the American psychologists." ${ }^{137}$ In addition to the personal relationship between Cattell and Scripture, both Scripture and Seashore adopted "an approach like Cattell's" to the study of sensation. ${ }^{38}$

A final set of clues to the link between Cattell and Seashore resides in the James McKeen Cattell Collection held by the Library of Congress. The author located more than seventy pieces of personal correspondence between the two men, the earliest dating from $1899 .^{39}$

Seashore's doctoral dissertation, which he completed in 1895, was about neither mental testing nor music. Instead, his interest in mental testing may have come indirectly from the prominent Cattell, whose article on the Columbia "Freshman Tests" appeared after Seashore completed his dissertation but before he published his first article on a music-related study. ${ }^{40}$ Cattell's work with music tests probably appealed to Seashore, a former singing school student, church organist and choir director, and college glee club director from an amateur musical family. ${ }^{41}$ 


\section{Conclusions}

Cattell learned from Wundt about the long German tradition of perception research, with its "precision, accuracy, order, and reproducibility of data and findings." 42 He may have become interested in individual differences under Hall. Under Galton, he developed his interest in the measurement of sensory perception differences between individuals. In addition, Galton's concepts about statistical correlation undoubtedly formed the basis for Cattell's hypotheses about relationships between mental ability and academic grades (and other "life tasks").

Despite the failure of Cattell's tests, his work "was of great importance as it was the first attempt to apply the 'new psychology' to problems of individual differences." 43 Nevertheless, he experienced difficulty in selecting valid, measurable dependent variables, a problem that continues to plague today's music education researchers. His main problem, however, was his presumably false hypothesis about strong relationships between mental ability and sensory perception ability. ${ }^{4}$

It is not surprising that Seashore and many other American psychologists followed Cattell and not Binet, because the latter's most important work appeared a few years later. However, most American researchers eventually joined Binet in defining intelligence as cognitive functioning ability, not as sensory perception ability. By contrast, Seashore's tests remained largely in the sensory perception realm, and he appears to have followed several other early mental testing researchers when he added (tonal) memory to his list of important "psychological processes," something that Cattell did not do. ${ }^{45}$ However, Binet and other mainstream mental testing researchers dropped "sensation, attention, perception, association, and memory" from their test batteries around $1904 .^{46}$

Seashore retained his 1890 s belief about yet another issue: that a series of mental tests could not yield a single score that represents general musical (or intellectual) ability. That was Cattell's position and Binet's, but subsequent American testing researchers went on to develop the concept of the intelligence quotient and other unitary measures of mental ability. On that issue, at least, Seashore's conservatism aligned his work with current thinking, which has now returned to that position.

\section{Implications for Music Education}

Cattell, the leading sensory mental tester of the $1890 \mathrm{~s}$, formally tested his first complete battery in the 1890s. Seashore, the leading sensory musical tester, formally tested his first complete battery in the 1910s, some twenty years later. Binet and Henri published their first battery of cognitive-type tests in 1904, only a few years after Cattell's sensory tests failed to predict academic achievement. Other researchers further developed the French tests in the first decade of the twentieth century, and have continued to develop them to this day.

By contrast, the field of music waited until 1965 for the appearance of a wellconstructed test that corresponded to the second generation of intelligence tests. ${ }^{47}$ Researchers now question the validity of this second generation of tests, both of intelligence and of musical aptitude. Both types of tests predict performance on schoolrelated tasks, ${ }^{48}$ but not necessarily on "life tasks."

Two central historical questions remain. First, why did Seashore, unlike Cattell, not abandon the effort after his tests failed to demonstrate predictive validity? In other words, why did Seashore remain committed to sensory measures when his (mostly American) counterparts in other fields shifted from tests of sensory perception to tests of reasoning and judgment?

It was partly a matter timing, Seashore having received his doctoral training and

begun his research program during the crucial few years between Cattell's bold hypothesis about relationships between sensory skills and mental ability and the failure of 
his statistical correlations to support that hypothesis. By the time failure was reported, Seashore may have already committed himself to his life-long agenda. After all, Binet and Henri's "key article"--in which they "argued for mental testing based not on sensory and motor functions but on the psychological processes thought to be involved in intelligence . . .49-appeared in 1895, the year Seashore received his doctorate.

It is also probable that Seashore believed that musical ability really is based largely on sensory ability, and therefore is somehow different from other mental abilities. Regardless, years later, Seashore explained that he had "drifted gradually into the field of psychology of music primarily for two reasons: first, my love of music and realization of great possibilities in an unworked field; and, secondly," because his first research interest, vision, plagued its research subjects with eye fatigue, a problem that did not trouble aural researchers. ${ }^{50}$

The second question is: Since Seashore did not turn to other types of tests, why did other music researchers not do so either? Almost from the beginning, critics charged that Seashore's battery was sensory and atomistic, but no one, including his most prominent critic, Columbia University psychologist James Mursell (1893-1963), ${ }^{51}$ conducted extensive, rigorous research on the tests or developed alternative measures. The lack of research-oriented graduate training in music education undoubtedly hampered the profession's efforts to test the validity of Seashore's battery thoroughly and to keep pace with new developments in the mental testing and research worlds generally. ${ }^{52}$ In addition, Seashore himself--with his Yale Ph.D. in the "scientific" field of psychology, his deanship at the University of Iowa and presidency of the American Psychological Association, and his tireless research efforts and prolific publication record-brought considerable prestige to the field of musical aptitude testing.

Indeed, unlike most other earlier sensory mental testing researchers, Seashore never changed his mind about the sensory nature of mental (musical) aptitude, although eventually he tacitly acknowledged the possibility of other types of "musical capacity" when he wrote, in 1930, that his six published measures "furnish a fairly good index to music capacity on the sensory side." ${ }^{3}$ Given his professional prestige and that of the field of psychology, and in the absence of strong evidence against his claims or of alternative approaches to musical aptitude testing, Seashore's tests stood nearly alone for a long time.

An implication of this historical research is that the field of music education can benefit from the research of prominent individuals from outside the field. Wundt, Galton, Cattell, and Seashore developed some of the concepts and research methods and tools still in use today. Each made large intellectual "leaps of faith" and each worked diligently to test his hypotheses. Each rendered the field a great service, directly or indirectly. In particular, this story of James Cattell and Carl Seashore suggests that music educators should consider carefully the contributions and prestige brought by those from outside the field. Seashore himself mentioned that he had been "more or less justly the butt of criticism from the musical profession." However, he also wrote that:

In the field of diagnosing musical talent, I have had a rather extraordinary following, but unfortunately much of it a gullible and non-critical type on the part of people who would take an isolated element in my procedure and handle it as if it covered the whole situation. . $^{4}$

Clearly, it is incumbent upon music educators to decide which contributions to embrace, which to disregard, and which to use as building blocks for the next generation of ideas. 
Notes

1 Carl E. Seashore, Seashore Measures of Musical Talent (New York: The Psychological Corporation, 1919).

2 Jere T. Humphreys, "Precursors of Musical Aptitude Testing: From the Greeks through the Work of Francis Galton," Journal of Research in Music Education 41 (Winter 1993): 315-27.

3 Edwin G. Boring, A History of Experimental Psychology, 2d ed. (New York: Appleton CenturyCrofts, 1950), 569.

4 The other two "great topics," learning and motivation, did not emerge until a few years later. Humphreys, "Precursors," 323.

5 Ibid., 316-17.

6 Charles Darwin, in his The Descent of Man and Selection in Relation to Sex, 2d ed. (New York: American Publishers Corporation, 1874), had argued that sensitivity to pitch is important in the natural selection process because "the vocal organs were primarily used and perfected in relation to the propagation of the species" (589).

Humphreys, "Precursors," 318-19.

8 Ibid., 319. Attempts to measure mental ability had occurred at least since the early nineteenth century. According to Florence Goodenough, Mental Testing: Its History, Principles, and Applications (New York: Rinehart and Company, 1949), 3, the first major work along those lines was produced in France and differentiated between mental deficiency and mental disease. Jean-Etienne Dominique Esquirol, Des maladies mentales considé rées sous les rapports médical, hygienique, et médico-légal, vols. I, II and atlas (Paris: J. B. Bailliére, 1838). Galton knew from this research that idiots and imbeciles frequently exhibit inferior sensory acuity, so he hypothesized a relationship between sensory acuity and intelligence. Richard Hermstein, I.Q. in the Meritocracy (Boston: Little, Brown, 1973), 63.

9 Humphreys, "Precursors," 321. Galton developed his first regression line from the size of "mother" and "daughter" peas. Karl Pearson, The Life, Letters and Labours of Francis Galion, vol. IIIA (Cambridge, England: Cambridge University Press, 1930), 3-5, 69.

10 Humphreys, "Precursors," 319-20.

11 Controversy remains over whom should be credited with establishing the first psychological laboratory in the United States: Hall at Johns Hopkins in early 1883 or William James at Harvard University around 1876. The controversy centers on whether 'James' room for demonstrational experiments at Harvard" was really a laboratory. J. McKeen Cattell, "Early Psychological Laboratories," Science 67 (May 1928): 546.

12 Most biographical accounts state that Cattell went to Pennsylvania in 1888, but he himself wrote later that he founded the laboratory there in 1887. Ibid., 546. Published accounts of Cattell's life differ in many details as to his exact whereabouts at specific times before his extended stays abroad ended in 1894. Numerous personal letters, primarily to his parents, suggest that he traveled frequently between Leipzig, Cambridge, and various other places in the United States and Europe. E.g., Jim [James McKeen Cattell], Leipzig, letters to "Mama and Papa" [William and Elizabeth Cattell], Philadelphia, 25 July 1894 and 5 December 1894, in James McKeen Cattell Collection, Container \#55, "Family Correspondence," December 1888-March 1903, Manuscript Division, Library of Congress, Washington, DC. The most complete account of Cattell's activities from 1880-1888 appears in Michael M. Sokal, ed., An Education in Psychology: James McKeen Cattell's Journal and Letters from Germany and England, 1880-1888 (Cambridge, MA: The MTT Press, 1981).

13 Ibid., 70, note 3.

14 J. McKeen Cattell, "Ueber die Trägheit der Netzhaut und des Sehcentrums," Philosophische Studien 3 (1885): [94-127]; reprinted as "The Inertia of the Eye and Brain," (no trans.) in James McKeen Cattell, James McKeen Cattell, 1860-1944: Man of Science, vol. I (Lancaster, PA: The Science Press, 1947), 27. (Page citation is to the reprint edition.)

15 James McKeen Cattell], Leipzig, letter to Francis Galton, Cambridge, England, [n.d. given], quoted in Francis Galton, "On Recent Designs for Anthropometric Instruments," The Joumal of the Anthropological Institute of Great Britain and Ireland 16 (1887): 8. Several of Cattell's journal entries and letters to his parents beginning in 1884 also contain references to his involvement with apparatus in Wundt's Leipzig laboratory. E.g., Sokal, Education, 98-105. 
16 James McKeen Cattell, "The Psychological Laboratory at Leipsic [sic]," Mind 13 (January 1888): 43.

17 Sokal, Education, 70, note 3. Although Galton is usually regarded as the first to study individual differences and was the undisputedly leader of the movement, Hall was eclectic and progressive and, like other psychologists in the child-study movement, eventually became interested in the characteristics of individual children. Jere T. Humphreys, "The ChildStudy Movement and Public School Music Education," Journal of Research in Music Education 33 (Summer 1985): 82.

18 Humphreys, "Precursors," 319.

19 J. McKeen Cattell, "Ueber die Zeit der Erkennung und Benennung von Schriftzeichen, Bildem und Farben." Philosophische Studien 2 (1885): 635-50; translated by R. S. Woodworth as "On the Time Required for Recognizing and Naming Letters and Words, Pictures and Colors," in Cattell, Cattell, vol. I, 13-25. Years later, Cattell gave this revealing account of Wundt's reactions to his early work on individual differences: . . . in my second interview with Wundt [probably in 1883] I presented an outline of the work I wanted to undertake, which was the objective measurement of the time of reactions with special reference to individual differences. Wundt said that. . . only psychologists could be the subjects in psychological experiments. I later bought and made the apparatus needed and did the work in my own room, without, however, any interruption in relations that were then becoming friendly. J. McKeen Cattell, "In Memory of Wilhelm Wundt," Psychological Reoiew 28 (May 1921): 156.

20 E.g., Jim [James McKeen Cattell], Cambridge, letter to "Mama and Papa," Philadelphia, 23 November 1893, James McKeen Cattell Collection, Container \#55.

21 James McKeen Cattell, "Psychology at the University of Pennsylvania," American Journal of Psychology 3 (April 1890): 282.

22 James McKeen Cattell, "Mental Tests and Measurements, Mind 15 (January 1890): 373-80.

23 Katherine W. Linden and James D. Linden, Modern Mental Measurement: A Historical Perspective (Boston: Houghton Mifflin Company, 1968), 9-10.

24 Cattell, "Mental Tests," 378. Cattell acknowledged his indebtedness to Galton in that article, when he wrote that Galton had "already used some of these tests, and I hope the series here suggested will meet with his approval" $(373$, note 1$)$.

J. McKeen Cattell and Livingston Farrand, "Physical and Mental Measurements of the Students of Columbia University," Psychological Review 3 (1896): 636.

Clark Wissler, "The Correlation of Mental and Physical Tests," Psychological Reoiew Monograph Supplements 3 (Whole No. 16) Oune 1901): 1-62.

27 Ibid., 9.

28 Ibid., 6, 15-17. The present author translated Wissler's archaic statistical terms and symbols to modern usage.

Ibid., 21-22. Wissler did not report exact significance levels for these and most of his other statistical tests.

30 Ibid., 54, 61-62.

31 For more information see Linden and Linden, 10.

32 Frank Boas, "Anthropological Investigations in Schools," Pedagogical Seminary 1 (June 1891): 22528; Joseph Jastrow, "Some Anthropometric and Psychologic [sic] Tests on College Students: A Preliminary Survey," American Journal of Psychology 4 (April 1892): 420-28; I. Allen Gilbert, "Researches on Mental and Physical Development of School-Children," in Studies from the Yale Psychological Laboratory, vol. II, ed. E. W. Scripture (New Haven, CT: Yale University Press, 1894); and J. Allen Gilbert, "Researches upon School Children and College Students," in Unioersity of Iowa Studies in Psychology, vol. I, ed. George T. W. Patrick and J. Allen Gilbert (lowa City: State University of Iowa, 1897). One of Gilbert's testing experiments involved music: J. A. Gilbert, "Experiments on the Musical Sensitiveness of School Children," in Studies from the Yale Psychological Laboratory, vol. I, ed. E. W. Scripture (New Haven, CT: Yale University Press, 1893).

33 A. Binet and V. Henri, "La Psychologie individuelle," L'année psychologique 2 (1895): 411-65; excerpts translated by Mollie D. Boring in A Source Book in the History of Psychology, ed. Richard J. Herrnstein and Edwin G. Boring (Cambridge, MA: Harvard University Press, 
1965), 428-33; and Hugo Münsterberg, Zur individual Psychologie," Centralbiatt f. nervenkeilkunde und psychiatrie 14 (1891): 196-98.

34 Cattell and Farrand, 623.

35 Humphreys, "Precursors," 322.

36 Michael M. Sokal, "The Unpublished Autobiography of James McKeen Cattell," American Psychologist 26 (July 1971): 629. Evidence that Cattell never completely gave up on his "Freshman Tests" can be found in a report written in 1922. J. M. Cattell, "The First Year of the Psychological Corporation," unpublished report, 1 December 1922, in James McKeen Cattell Collection, Container \#178, "Subject File," 1890-1936, Manuscript Division, Library of Congress, Washington, DC.

37 Michael M. Sokal, "Biographical Approach: The Psychological Career of Edward Wheeler Scripture," in Historiography of Modern Psychology: Aims, Resources, Approaches, ed. Josef Brozek and Ludwig J. Pongratz (Toronto: C. J. Hogrefe, Inc., 1980), 268. Cattell, for example, praised one of Scripture's books, Edward Wheeler Scripture, The New Psychology (New York: Scribner's, 1897), when other psychologists criticized it harshly. Sokal, "Biographical," 266-67. In addition, Cattell apparently helped Scripture become a fellow of the American Association for the Advancement of Science. [Edward Wheeler] Scripture, New Haven, CT, letter to [James McKeen] Cattell, New York, NY, 7 August 1901, in James McKeen Cattell Collection, Container \#38, "General Correspondence," 1884-1944, Manuscript Division, Library of Congress, Washington, DC. In 1902, Scripture visited Cattell about his future plans, just before he was released by Yale later that year. After earning a medical degree in his native Germany and teaching briefly at Johns Hopkins, both Scripture and his wife obtained positions at Columbia, "possibly with Cattell's help." Sokal, "Biographical," 269-70.

38 Tbid., 256.

39 James McKeen Cattell Collection, Container \#38. Years later, Cattell and others collaborated with Seashore to found the nonprofit Psychological Corporation. Their correspondence continued through the 1930s. James McKeen Cattell, New York, NY, various letters, memoranda, and undated manuscripts, James McKeen Cattell Collection, Container \#178.

40 One of Seashore's first music-related publications was his "Hearing-ability and Discriminative Sensibility for Pitch," in University of Iowa Studies in Psychology, vol. II, ed. G. T. W. Patrick (Iowa City: State University of Iowa, 1899). His doctoral dissertation was "Measurements of Illusions and Hallucinations in Normal Life" (Ph.D. diss., Yale University, 1895); published in Studies from the Yale Psychological Laboratory, vol. III, ed. E. W. Scripture (New Haven, CT: Yale University Press, 1895). Interestingly, Scripture began to study pitch perception, but not mental testing per se, during Seashore's student years at Yale. E. W. Scripture, "The Method of Regular Variation," in "Psychological Notes," American Journal of Psychology 4 (August 1892): 577-84.

41 Carl Emil Seashore, "Carl Emil Seashore," in A History of Psychology in Autobiography, vol. I, ed. Carl Murchison (Worcester, MA: Clark University Press, 1930; reprint, New York: Russell \& Russell, 1961), 236-38, 245. (Page citations are to the reprint edition.)

42

43

44

45

46

47

48

49

Linden and Linden, 5.

Sokal, "Unpublished," 629.

Cattell may yet be proven correct. Recently, Deary reported a strong link between intelligence and auditory ability. Ian J. Deary, "Intelligence and Auditory Discrimination: Separating Processing Speed and Fidelity of Stimulus Representation," Intelligence 18 (March 1994): 189-213.

Philip H. DuBois, A History of Psychological Testing (Boston: Allyn and Bacon, 1970), 28.

Ibid., 46.

Edwin Gordon, Musical Aptitude Profile (Boston: Houghton Mifflin Company, 1965). The "Musical Sensitivity" portion of this test clearly represents a move away from sensory measurement.

Various aptitude tests, including those of musical aptitude, predict achievement in school music. See Jere T. Humphreys, William V. May, and David J. Nelson, "Research on Music Ensembles," in Handbook of Research on Music Teaching and Learning, ed. Richard Colwell (New York: Schirmer Books, 1992), 651-53.

Hermstein, 65. The "key article" was Binet and Henri, "La psychologie individuelle." 
50 Seashore, "Seashore," 272. Interestingly, neither Cattell nor Galton investigated the relationships between sensory ability and musical aptitude per se. Rather, Galton gathered antecdoctal data about artistic ability and compared them to expected statistical values. Humphreys, "Precursors," 322.

51 Among his many writings about the Seashore tests is James L. Mursell, The Psychology of School Music Teaching (New York: Silver, Burdett and Company, 1931), 333-35.

52 Jere T. Humphreys, "Applications of Science: The Age of Standardization and Efficiency in Music Education," The Bulletin of Historical Research in Music Education 9 (January 1988): 1718.

53 Seashore, "Seashore," 273-74. Seashore's statement stands in contrast to the reflections of one of his contemporaries published in the same year, the prominent mental tester Joseph Jastrow of the University of Wisconsin: My interest in the subject goes back to 1893 and before. In that early period Cattell had emphasized the importance of tests of indices of individual differences. . . . But it remained for Binet . . . to recognize in ordinary achievements (not merely in specially arranged sensory, motor, memory, and intelligence functions, such as I had used) an available means of grading natural aptitudes. Joseph Jastrow, "Joseph Jastrow," in A History of Psychology in Autobiography, vol. I, ed. Carl Murchison (Worcester, MA: Clark University Press, 1930; reprint, New York: Russell \& Russell, 1961), 156. (Page citation is to the reprint edition.)

54 Seashore, "Seashore," 272.

\section{Bibliography}

Binet, A., and V. Henri. "La psychologie individuelle." L'année psychologique 2 (1895): 411-65. Excerpts translated by Mollie D. Boring. In A Source Book in the History of Psychology, ed. Richard J. Hermstein and Edwin G. Boring, 428-33. Cambridge, MA: Harvard University Press, 1965.

Boas, Frank. "Anthropological Investigations in Schools." Pedagogical Seminary 1 (June 1891): 225-28.

Boring, Edwin G. A History of Experimental Psychology. 2d ed. New York: Appleton Century-Crofts, 1950.

Cattell, J. McKeen. "Early Psychological Laboratories." Science 67 (May 1928): 543-48.

"The First Year of the Psychological Corporation." Unpublished report to the Board of Directors, 1 December 1922. James McKeen Cattell Collection, Container \#178, "Subject File, 1890-1936. Manuscript Division, Library of Congress, Washington, DC.

James McKeen Cattell, 1860-1944: Man of Science. Vol. I (Lancaster, PA: The Science Press, 1947).

Cambridge [England], to "Mama and Papa" [William and Elizabeth Cattell], Philadelphia, 23 November 1893, 25 July 1894, 5 December 1894. Letters in the hand of James McKeen Cattell. James McKeen Cattell Collection, Container \#55, "Family Correspondence," December 1888-March 1903. Manuscript Division, Library of Congress, Washington, DC. (Two of these letters are misfiled in the Collection.)

Leipzig [Germany], to Francis Galton, Cambridge [England], [n.d. given]. Quoted in Francis Galton. "On Recent Designs for Anthropometric Instruments." The Journal of the Anthropological Institute of Great Britain and Ireland 16 (1887): 2-9.

"In Memory of Wilheim Wundt." Psychological Reoiew 28 (May 1921): 155-59.

"Mental Tests and Measurements." Mind 15 (January 1890): 373-80.

"The Psychological Laboratory at Leipsic [sic]." Mind 13 (January 1888): 37-51.

"Psychology at the University of Pennsylvaria." American Journal of Psychology 3 (April 1890): 281-83.

"Ueber die Trägheit der Netzhaut und des Sehcentrums." Philosophische Studien 3 (1885): 94 127. Reprinted as "The Inertia of the Eye and Brain." In (no translator) James McKeen Cattell. James McKeen Cattell, 1860-1944: Man of Science. Vol. I, 26-40. Lancaster, PA: The Science Press, 1947.

"Ueber die Zeit der Erkennung und Benennung von Schriftzeichen, Bildern und Farben." Philosophische Studien 2 (1885): 635-50. Excerpts translated by R. S. Woodworth in "On the 
Time Required for Recognizing and Naming Letters and Words, Pictures and Colors." In James McKeen Cattell. James McKeen Cattell, 1860-1944: Man of Science. Vol. I, 13-25. Lancaster, PA: The Science Press, 1947.

Cattell, J. McKeen, and Livingston Farrand. "Physical and Mental Measurements of the Students of Columbia University. Psychological Review 3 (1896): 618-48.

Darwin, Charles. The Descent of Man and Selection in Relation to Sex, $2 d$ ed. New York: American Publishers Corporation, 1874.

Deary, Ian J. "Intelligence and Auditory Discrimination: Separating Processing Speed and Fidelity of Stimulus Representation." Intelligence 18 (March 1994): 189-213.

DuBois, Philip H. A History of Psychological Testing. Boston: Allyn and Bacon, 1970.

Esquirol, Jean-Etienne Dominique. Des maladies mentales considé rées sous les rapports médical, hygienique, et médico-légal. Vols. I, II and Atlas. Paris: J. B. Bailliére, 1838.

Galton, Francis. "On Recent Designs for Anthropometric Instruments." The Journal of the Anthropological Institute of Great Britain and Ireland 16 (1887): 2-9.

Gilbert, J. A. "Experiments on the Musical Sensitiveness of School Children." In Studies from the Yale Psychological Laboratory. Vol. I, ed. E. W. Scripture, 80-87. New Haven, CT: Yale University Press, 1893.

"Researches on Mental and Physical Development of School-Children." Studies from the Yale Psychological Laboratory. Vol. II, ed. E. W. Scripture, 40-100. New Haven, CT: Yale University Press, 1894.

"Researches upon School Children and College Students." University of Iowa Studies in Psychology. Vol. I, ed. G. T. W. Patrick and J. Allen Gilbert, 1-39. Iowa City: State University of Iowa, 1897.

Goodenough, Florence L. Mental Testing: Its History, Principles, and Applications. New York: Rinehart and Company, 1949.

Gordon, Edwin. Musical Aptitude Profile. Boston: Houghton Mifflin Company, 1965.

Herrnstein, Richard J. I.Q. in the Meritocracy. Boston: Little, Brown, 1973.

Herrnstein, Richard J., and Edwin G. Boring, eds. A Source Book in the History of Psychology. Cambridge, MA: Harvard University Press, 1965.

Humphreys, Jere T. "Applications of Science: The Age of Standardization and Efficiency in Music Education." The Bulletin of Historical Research iri Music Education 9 (January 1988): 1-21.

. "The Child-Study Movement and Public School Music Education." Journal of Research in Music Education 33 (Summer 1985): 79-86.

"Precursors of Musical Aptitude Testing: From the Greeks through the Work of Francis Galton." Journal of Research in Music Education 41 (Winter 1993): 315-27.

Humphreys, Jere T., William V. May, and David J. Nelson. "Research on Music Ensembles." In Handbook of Research on Music Teaching and Learning, ed. Richard Colwell, 651-68. New York: Schirmer Books, 1992.

Jastrow, Joseph. "Joseph Jastrow." In A History of Psychology in Autobiography. Vol. I, ed. Carl Murchison, 135-62. Worcester, MA: Clark University Press, 1930; reprint, New York: Russell \& Russell, 1961.

"Some Anthropometric and Psychologic [sic] Tests on College Students." American Journal of Psychology 4 (April 1892): 420-28.

Linden, Katherine W., and James D. Linden. Modern Mental Measurement: A Historical Perspective. Boston: Houghton Mifflin Company, 1968.

Münsterberg, Hugo. "Zur individual Psychologie," Centralblatt f. Neroenheilkunde und Psychiatrie 14 (1891): 196-98.

Mursell, James L. The Psychology of School Music Teaching. New York: Silver, Burdett and Company, 1931.

Pearson, Karl. The Life, Letters and Labours of Francis Galton. Vol. IIIA. Cambridge, England: Cambridge University Press, 1930. 
Scripture, [Edward Wheeler], New Haven, CT, to [James McKeen] Cattell, New York, NY, 7 August. 1901. Letter in the hand of Edward Wheeler Scripture. James McKeen Cattell Collection, Container \#38, "General Correspondence," 1884-1944. Manuscript Division, Library of Congress, Washington, DC.

. "The Method of Regular Variation," in "Psychological Notes." American Journal of Psychology 4 (August 1892): 577-84.

. The New Psychology. New York: Scribner's, 1897.

Seashore, Carl Emil. "Carl Emil Seashore." In A History of Psychology in Autobiography. Vol. I, ed. Carl Murchison, 225-97. Worcester, MA: Clark University Press, 1930; reprint, New York: Russell \& Russell, 1961.

"Hearing-ability and Discriminative Sensibility for Pitch." University of Iowa Studies in Psychology. Vol. II, ed. G. T. W. Patrick, 163-78. lowa City: State University of Iowa, 1899.

"Measurements of Mlusions and Hallucinations in Normal Life." Ph.D. diss., Yale University, 1895; published in Studies from the Yale Psychological Laboratory. Vol. III, ed. E. W. Scripture, 1-67. New Haven, CT: Yale University Press, 1895.

Seashore, Carl E. Seashore Measures of Musical Talent. New York: The Psychological Corporation, 1919.

Sokal, Michael M. "Biographical Approach: The Psychological Career of Edward Wheeler Scripture." In Historiography of Modern Psychology: Aims, Resources, Approaches, ed. Josef Brozek and Ludwig J. Pongratz, 255-78. Toronto: C.J. Hogrefe, Inc., 1980.

ed. An Education in Psychology: James McKeen Cattell's Journal and Letters from Germany and England, 1880-1888. Cambridge, MA: The MTT Press, 1981.

"The Unpublished Autobiography of James McKeen Cattell." American Psychologist 26 (July 1971): 626-35.

Wissler, Clark. "The Correlation of Mental and Physical Tests." Psychological Review Monograph Supplements 3 (Whole No. 16) (June 1901): 1-62.

\section{About the Author}

Jere T. Humphreys is Professor of Music (education) and Coordinator of Doctoral Studies in Music Education at Arizona State University, Tempe. He currently serves on the Executive Committees of the Music Educators National Conference's Music Education Research Council and the Society for Music Teacher Education. He has also served on the editorial committees of The Bulletin of Historical Research in Music Education, Update: Applications of Research in Music Education, the Southeastern Jourmal of Music Education. The Quarterly Journal of Music Teaching and Learning, the Bulletin of the Council for Research in Music Education, and the Journal of Band Research. An historical and empirical researcher, he has published in several journals and books and has made presentations in Africa, Asia, Europe and North America. 